\title{
Analisis Pengaruh Kompetensi Terhadap Kinerja Karyawan Pada PT. Pos Indonesia Cabang Soppeng
}

\author{
Mansur $^{1,}$ Asmini $^{2}$ \\ 1, 2 Program Studi Manajemen,Universitas Lamappapoleonro
}

\begin{abstract}
ABSTRAK
Penelitian ini dilakukan pada PT. Pos Indonesia Cabang Soppeng, berlokasi di Jalan Pengayoman Kelurahan Lemba Kecamatan Lalabata Watansoppeng, Sampel yang digunakan adalah sebanyak 32 Responden. Sedangkan teknik pengambilan sampel yaitu dengan menggunakan metode Sampling Jenuh. Untuk mengetahui pengaruh Kompetensi terhadap kinerja karyawan pada PT. POs Indonesia Cabang Soppeng digunakan Analisis Regresi Linear Berganda. Berdasarkan Analisis Regresi Berganda dapat diketahui Kompetensi yang terdiri dari variabel pengetahuan, keterampilan, perilaku dan pengalaman kerja memiliki pengaruh yang signifikan terhadap peningkatan kinerja karyawan pada PT. Pos Indonesia Cabang Soppeng. dapat diketahui bahwa diantara variabel pengetahuan, keterampilan, perilaku dan pengalaman kerja yang paling berpengaruh signifikan terhadap peningkatan kinerja karyawan pada PT. Pos Indonesia Cabang Soppeng adalah Pengalaman Kerja.
\end{abstract}

Pimpinan Kejaksaan Negeri Kabupaten Soppeng hendaknya memberikan perhatian khusus pada para pegawai dan lebih bertanggung jawab terhadap pekerjaan dan jabatan yang diembannya. Keberhasilan kinerja pegawai adalah salah satu unsur dalam meningkatkan kinerja organisasi. Diharapkan dengan tercapainya gaya kepemimpinan yang baik maka kinerja pegawai Kantor Kejaksaan Negeri Kabupaten Soppeng pun akan semakin baik., Peningkatan Kinerja pegawai Pada Kantor Kerjaksaan Negeri Kabuptaen Soppeng dapat melalui Komunikasi dengan meningkatkan Kualitas Media yang baik, Kecepatan, mengakses Informasi, Penyebaran Pesan, Ketepatan Pesan sehingga proses komunikasi antara Bawahan dan atasan serta rekan kerja Dapat terlaksana dengan efektif dan efisien, dan Perlu penelitian lanjutan untuk mengetahui faktor-faktor lain yang dapat mempengaruhi kinerja Pegawai Pada Kantor Kejaksaan Negeri Kabupaten Soppeng.

\section{Keywords:}

Kompetensi, Kinerja, Kinerja Karyawan

$\triangle$ Corresponding author:

Email Address : mansurylps09@gmail.com 


\section{Pendahuluan}

Dinamika bisnis dan dunia usaha menuntut organisasi untuk lebih dinamis. Dengan begitu, organisasi memerlukan sumber daya manusia yang mampu mengimbangi dinamika organisasi tersebut, yaitu sumber daya manusia yang memiliki nilai yang kuat, fleksibel dan dapat beradaptasi dengan perubahan lingkungan. Untuk itu sumber daya manusia harus memiliki kapasitas yang dibangun di atas pondasi yang kuat, yang sesuai dengan tuntutan usaha. Sumber daya manusia yang berbasis kompetensi dapat meningkatkan kapasitas dan membangun pondasi karena apabila orang-orang yang bekerja dalam organisasi memiliki kompetensi yang tepat sesuai dengan tuntutan pekerjaannya, maka dia akan mampu baik dari segi pengetahuan, keterampilan maupun mental serta karakter produktifnya. Dengan kepemilikan nilai (value) yang kuat, mereka akan selalu siap menghadapi perubahan sesuai dengan tuntutan organisasi tanpa menghilangkan jati dirinya.

Berdasarkan uraian tersebut di atas, maka penulis menentukan obyek penelitian pada perusahaan PT. Pos Indonesia Cabang Soppeng, yakni perusahaan yang bergerak di bidang jasa Ekspedisi, alasan pemilihan obyek penelitian ini disebabkan karena Pos Indonesia Cabang Soppeng saat ini masuk ke dalam kelompok Usaha menengah di Indonesia dari sisi aset, seiring dengan terbukanya kesempatan dan peningkatan kemampuan melayani kebutuhan masyarakat yang lebih luas, ke segmen komersial dan konsumer, dengan memberikan pelayanan secara konvensional maupun syariah, yang didukung oleh sistem pengelolaan dana yang optimal, kehandalan teknologi informasi, kompetensi sumber daya manusia dan praktek tata kelola perusahaan yang baik. Namun berdasarkan observasi awal Kinerja Karyawan pada PT. Pos Indonesia Cabang Soppeng masih tergolong rendah, hal ini dibuktikan dengan Masih Banyak karyawan yang tidak memiliki pengetahuan yang cukup tentang bidang pekerjaannya dan kurangnya keterampilan menggunakan komputer yang dimiliki karyawan sehingga seringkali menghambat pekerjaannya.

\section{Kajian Literatur}

Mangkunegara (2005:113) mengemukakan bahwa kompetensi merupakan faktor mendasar yang dimiliki seseorang yang mempunyai kemampuan lebih, yang membuatnya berbeda dengan seseorang yang mempunyai kemampuan rata-rata atau biasa saja. selanjutnya Donald dalam (Betty Zelda Siahaan, 2017)(Asmini, 2019), memperkenalkan kompetensi berdasarkan teori "Window"bahwa setiap pengembangan diri yang dimiliki manuasia dalam hal kompetensi dapat dilihat dari empat sisi yaitu pengetahuan (knowledge), keterampilan (skill), keahlian (expert), dan sikap (attitude). 
Kompetensi berdasarkan kepada pendapat C. Lynn dalam (Asmini, 2019) adalah:"competence range from recall and understanding of fact and concepts, to advanced motor skill, to teaching behaviours and profesional values" atau dengan kata lain, kompetensi dapat meliputipengulangan kembali fakta-fakta dan konsep-konsep sampai pada keterampilanmotorik lanjut hingga pada perilaku-perilaku pembelajaran dan nilainilaiprofesional

Kemudian Hutapea dan Thoha (2008:28) mengungkapkan bahwa ada empat komponen utama pembentukan kompetensi yaitu pengetahuan yang dimiliki seseorang, kemampuan, pengalaman, dan perilaku individu. Keempat komponen utama dalam kompetensi dapat dijelaskan lebih rinci sebagai berikut :

1. Pengetahuan

Yuniarsih dan Suwatno (2008:23) bahwa : "Pengetahuan adalah suatu informasi yang dimiliki seseorang khususnya pada bidang spesifik." Pengetahuan adalah informasi yang dimiliki oleh seseorang. Pengetahuan adalah komponen utama kompetensi yang mudah diperoleh dan mudah diidentifikasi.

2. Keterampilan

Faktor yang juga ikut mensukseskan pencapaian tujuan organisasi adalah faktor keterampilan karyawan. Bagi karyawan yang mempunyai keterampilan kerja yang baik, maka akan mempercepat pencapaian tujuan organisasi, sebaliknya karyawan yang tidak terampil akan memperlambat tujuan organisasi. Untuk karyawan-karyawan baru atau karyawan dengan tugas baru diperlukan tambahan keterampilan guna pelaksanaan tugas-tugas yang dibebankan kepadanya.

3. Perilaku

Disamping pengetahuan dan ketrampilan karyawan, hal yang perlu diperhatikan adalah sikap perilaku kerja karyawan. Apabila karyawan mempunyai sifat yang mendukung pencapaian tujuan organisasi, maka secara otomatis segala tugas yang dibebankan kepadanya akan dilaksanakan dengan sebaik-baiknya. Menurut Gitosudarmo dan Sudita (2008:23) mengemukakan bahwa : "Perilaku kerja adalah sikap keteraturan perasaan dan pikiran seseorang dan kecenderungan bertindak terhadap aspek lingkungannya."

4. Pengalaman Kerja

Menurut Manullang (2002:84) bahwa : "Pengalaman kerja adalah proses pembentukan pengetahuan atau keterampilan tentang metode suatu pekerjaan karena keterlibatan 
karyawan tersebut dalam pelaksanaan tugas pekerjaan. Pengalaman adalah keseluruhan pelajaran yang diperoleh seseorang dari peristiwa-peristiwa yang dialami dalam perjalanan hidup. Pengalaman yang dapat membentuk kompetensi seseorang misalnya pengalaman yang diperoleh dari bekerja dan berorganisasi.

Kinerja adalah penentuan secara periodik efektivitas operasional organisasi, bagian organisasi dan karyawannya berdasarkan sasaran, standar dan kriteria yang telah ditetapkan sebelumnya (Srimindarti dalam Asmini, Sukma Aini, 2020). Menurut Mangkunegara dalam (Asmini, Sukma Aini, 2020) kinerja adalah hasil kerja secara kualitas dan kuantitas yang dapat dicapai oleh seorang pegawai dalam melaksanakan tugas sesuai dengan tanggung jawab yang diberikan kepadanya.

H1: Kompetensi yang terdiri dari variabel pengetahuan, keterampilan, perilaku dan pengalaman kerja memiliki pengaruh yang signifikan terhadap peningkatan kinerja karyawan pada PT. Pos Indonesia Cabang Soppeng.

H2: Diantara variabel pengetahuan, keterampilan, perilaku dan pengalaman kerja yang paling berpengaruh signifikan terhadap peningkatan kinerja karyawan pada PT. Pos Indonesia Cabang Soppeng adalah pengetahuan.

Gambar 1. Kerangka Pikir

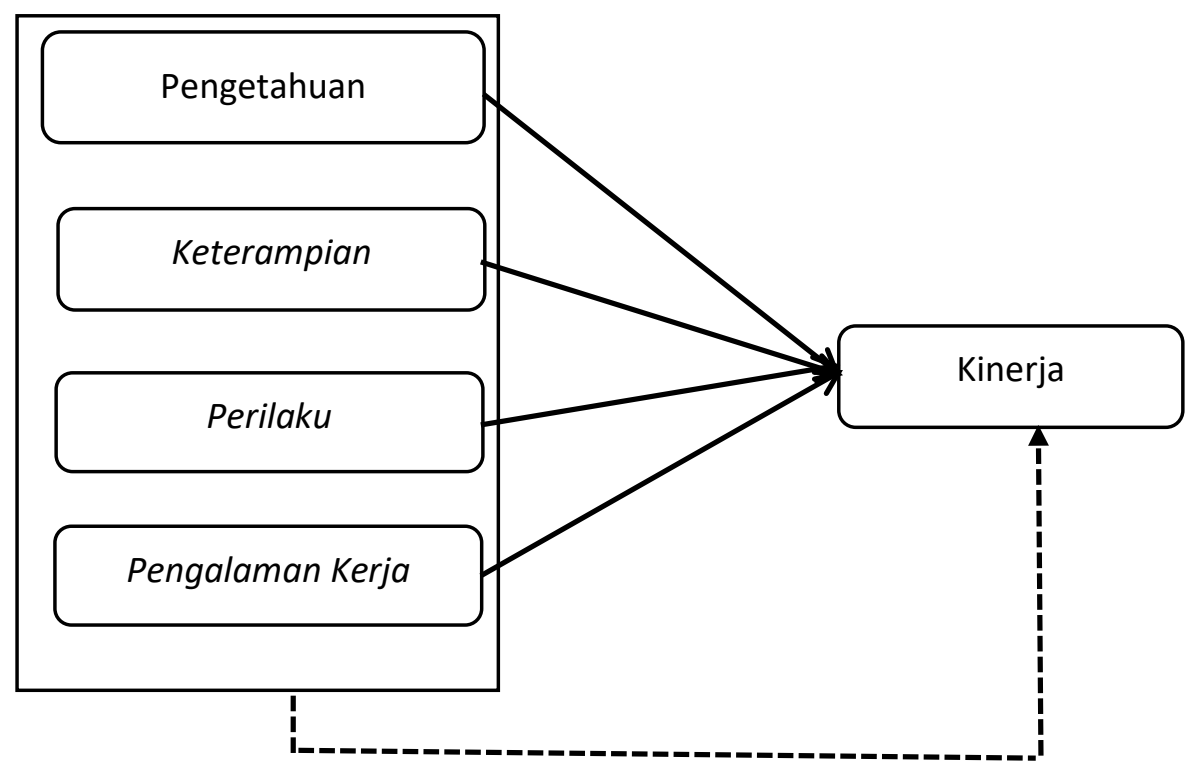

Keterangan :

1. Garis Putus Putus Hubungan Simultan

2. Garis Bersambung Hubungan Parsial 


\section{Method, Data, and Analysis}

Pendekatan penelitian yang dilakukan ini melalui beberapa tahapan, yakni diawali dengan mengumpulkan data melalui penyebaran kuesioner kepada sejumlah responden yang menjadi sampel penelitian, menentukan instrumen penelitian, menentukan metode yang dipergunakan, serta menganalisis data yang sudah terkumpul kemudian disajikan dalam bentuk deskriptif.

Populasi dalam penelitian ini adalah seluruh karyawan pada PT. Pos Indonesia Cabang Soppeng, berjumlah sebesar 32 orang karyawan. Sehingga metode penarikan sampel digunakan dengan cara sensus atau Sampel Jenuh, yakni jumlah keseluruhan populasi dapat dijadikan sebagai jumlah sampel dalam penelitian ini, sehingga sampel ditentukan sebesar 32 orang.

Pelaksanaan pengumpulan data penelitian ini dilakukan dengan metode:

a. Observasi, Yaitu teknik pengumpulan data yang dilakukan dengan mengadakan pengamatan langsung terhadap aktivitas sumber daya manusia yang ada pada PT. Pos Indonesia Cabang Soppeng,

b. Wawancara, Yaitu teknik pengumpulan data yang dilakukan dengan mengadakan tanya jawab langsung dengan responden dan pihak-pihak yang ada kaitannya dengan masalah yang akan diteliti.

c. Kuesioner, Yaitu teknik pengumpulan data yang dilakukan dengan memberikan daftar pertanyaan untuk diisi oleh para responden dan diminta untuk memberikan pendapat atau jawaban atas pertanyaan yang diajukan.

Metode analisis yang digunakan untuk menganalisis data yang di peroleh sekaligus untuk menguji hipotesis yang telah diajukan dalam penelitian ini adalah sebagai berikut:

1. Analisis deskriptif adalah suatu analisis yang dilakukan untuk memberikan gambaran secara umum terhadap obyek yang diteliti melalui data sampel atau populasi yang diteliti, khususnya mengenai berkompetensi terhadap kinerja karyawan.

2. Analisis regresi berganda yaitu suatu analisis yang menguji pengaruh pengetahuan, keterampilan dan perilaku terhadap kinerja karyawan, dengan menggunakan rumus Riduwan dan Akdom, (2007:142) sebagai berikut:

$$
Y=b_{0}+b_{1} X_{1}+b_{2} X_{2}+b_{3} X_{3}+b_{4} X_{4}+e
$$


Dimana:

$\mathrm{Y}$ = Kinerja karyawan

$\mathrm{X}_{1}=$ Pengetahuan

$\mathrm{X}_{2}=$ Ketrampilan

$\mathrm{X}_{3}=$ Perilaku

$\mathrm{X}_{4}=$ Pengalaman kerja

$b_{1}, b_{2}, b_{3}, b_{4}=$ Koefisien regresi

$\mathrm{e}=$ Error

\section{Hasil Penelitian dan Pembahasan}

\subsection{Hasil Analisis Regresi}

Analisis pengaruh variabel-variabel Kompetensi yang terdiri dari variabel Pengetahuan, Keterampilan, Perilaku dan Pengalaman Kerja terhadap kinerja karyawan PT. Pos Indonesia Cabang Soppeng dapat diketahui setelah dilakukan pengujian hipotesis. Pengujian hipotesis menggunakan analisis statistik inferensial dengan teknik analisis regresi linear berganda (multiple linear regression analysis). Untuk pengujian hipotesis variabel berpengaruh atau variabel bebas (independent variabel) secara bersama-sama terhadap variabel tidak bebas (dependent variable) digunakan analisis regresi linear berganda. Hasil pengujian hipotesis secara lengkap dapat dilihat pada lampiran.

Hasil analisis regresi linear berganda pengaruh variable Kompetensi yang terdiri dari Pengetahuan, Keterampilan, Perilaku dan pengalaman kerja terhadap kinerja karyawan PT. Pos Indonesia Cabang Soppeng dapat dilihat pada tabel 1.

Tabel 1

Konstanta dan Koefisien Regresi dari Variabel Kompetensi Berpengaruh Terhadap Kinerja

Karyawan

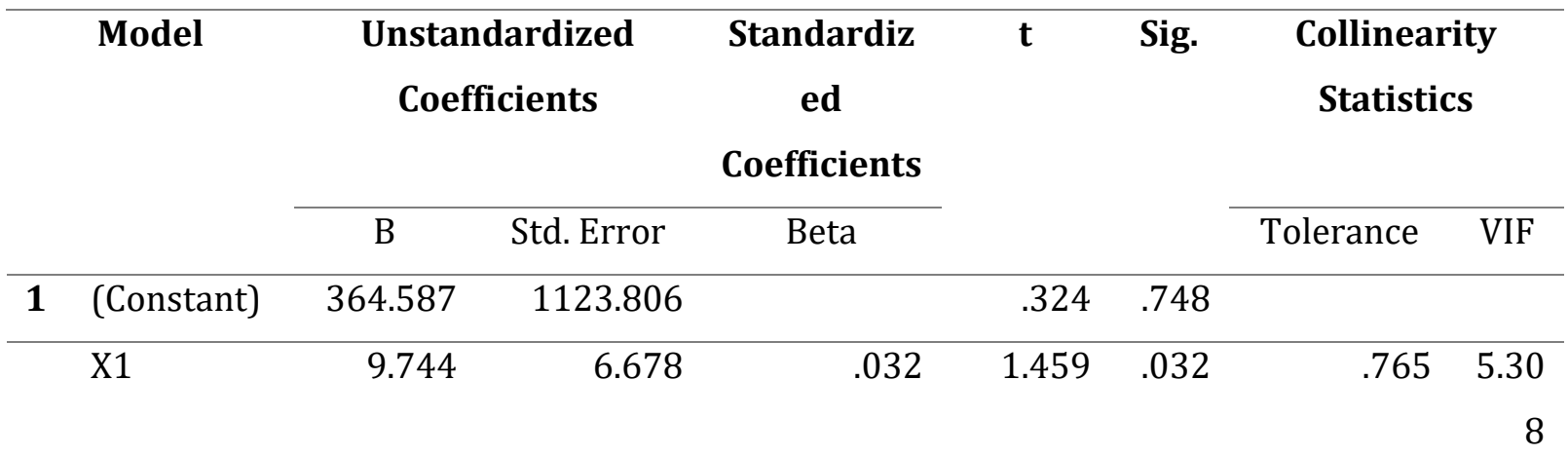




\begin{tabular}{rrrrrrrr}
\hline $\mathrm{X} 2$ & 9.203 & 5.235 & .055 & 1.64 & .013 & .866 & 5.16 \\
& & & & & & 7 \\
\hline $\mathrm{X} 3$ & 1.943 & 4.939 & .072 & .393 & .024 & .986 & 1.01 \\
& & & & & & 4 \\
\hline $\mathrm{X} 4$ & 10.598 & 1779.226 & .110 & .556 & .006 & .952 & 1.05 \\
& & & & & & & 0
\end{tabular}

Dari tabel tersebut diperoleh persamaan regresi linear berganda sebagai berikut :

$$
Y=364,587+9,744 X_{1}+9,203 X_{2}+1,943 X_{3}+10,598 X_{4}
$$

Dari persamaan regresi tersebut dapat diketahui pengaruh Pengetahuan dengan nilai koefisien $\left(b_{1}\right)$ = 9,744 yang berarti bahwa bila skor variabel Pengetahuan bertambah 1 poin sementara variabel lainnya dipertahankan maka akan meningkatkan kinerja karyawan sebesar 9,744 poin . dengan tingkat signifikan $(p)=0,032<$ taraf kesalahan $(\alpha)=0,05$ maka variabel Pengetahuan berpengaruh Positif dan signifikan terhadap kinerja karyawan.

Variabel Keterampilan dengan nilai koefisien $\left(b_{2}\right)=9,203$ yang berarti bahwa bila skor variabel Keterampilan bertambah 1 poin sementara variabel lainnya dipertahankan maka akan meningkatkan kinerja karyawan sebesar 9,203 poin. dengan tingkat signifikan $(p)=0,000>\alpha=$ 0,013 maka variabel Keterampilan berpengaruh Positif dan Signifikan terhadap kinerja karyawan.

Variabel Perilaku dengan nilai koefisien $b_{3}=1,943$ yang berarti bahwa bila skor variabel Perilaku bertambah 1 poin sementara variabel lainnya dipertahankan maka akan meningkatkan kinerja pegawai sebesar 1,943 poin. dengan tingkat signifikan $(\mathrm{p})=0,024>\alpha=0,05$ maka pengaruh variabel Perilaku terhadap kinerja karyawan positif dan signifikan.

Selanjutnya Variabel Pengalaman Kerja dengan nilai koefisien $\left(b_{4}\right)=10,598$ yang berarti bahwa bila skor variabel Pengalaman Kerja bertambah 1 poin sementara variabel lainnya dipertahankan maka akan meningkatkan kinerja karyawan sebesar 10,598 poin. dengan tingkat signifikan $(p)=0,006>\alpha=0,05$ maka variabel Pengalaman Kerja berpengaruh Positif dan Signifikan terhadap kinerja karyawan.

Analisis selanjutnya mengenai variabel-variabel yang berpengaruh secara simultan terhadap kinerja karyawan PT. Pos Indonesia Cabang Soppeng dapat dilihat pada tabel 2

Tabel 2

Tabel ANOVA Variabel-Variabel Berpengaruh Secara Simultan Terahadap Kinerja Karyawan 


\begin{tabular}{|c|c|c|c|c|c|c|}
\hline \multicolumn{7}{|c|}{ ANOVA $^{\mathbf{b}}$} \\
\hline \multirow{2}{*}{ Model } & $\begin{array}{c}\text { Sum of } \\
\text { Squares }\end{array}$ & df & $\begin{array}{c}\text { Mean } \\
\text { Square }\end{array}$ & F ig. & \\
\hline 1 & Regression & $1.857 \mathrm{E} 7$ & 4 & 4641902.3 & 1.893 & $.003^{\mathrm{a}}$ \\
& & & 91 & & \\
\cline { 2 - 8 } & Residual & $1.403 \mathrm{E} 8$ & 27 & 5195320.0 & & \\
& & & & 61 & & \\
\cline { 2 - 8 } & Total & $1.588 \mathrm{E} 8$ & 31 & & & \\
\hline
\end{tabular}

a. Predictors: (Constant),Pengetahuan, Keterampilan, Periilaku, Pengalaman Kerja

b. Dependent Variable: Kinerja Karyawan

Sumber : Data primer diolah tahun 2021

Dari tabel ANOVA diatas diperoleh nilai $\mathrm{F}_{\text {hitung }}=1,893$ dengan angka signifikansi $(\mathrm{p})=$ $0,003<\alpha=0,05$ yang berarti bahwa Ho ditolak dan $\mathrm{H}_{\mathrm{a}}$ diterima. Atau dengan kata lain, memang benar bahwa variabel Kompetensi yang terdiri dari Pengetahuan, Keterampilan, Perilaku dan Pengalaman kerja secara simultan berpengaruh terhadap kinerja karyawan PT. Pos Indonesia Cabang Soppeng.

Dari hasil penelitian tersebut diketahui bahwa variabel Pengalaman Kerja mempunyai pengaruh paling dominan dari keempat variabel yang diuji terhadap kinerja karyawan PT. Pos Indonesia Cabang Soppeng yang ditandai oleh nilai koefisien regresi paling besar yaitu sebesar 10,598, disusul variabel Pengetahuan 9,744, dan variabel Keterampilan yaitu sebesar 9,203, kemudian variabel Perilaku yaitu 1,943 Dengan demikian, hipotesis yang telah dikemukakan sebelumnya yang menyatakan bahwa diduga Variabel Pengetahuan paling dominan pengaruhnya terhadap kinerja tidak terbukti.

\subsection{Pembahasan}

\subsubsection{Pengaruh Pengetahuan Terhadap Kinerja Karyawan}

Dari persamaan regresi tersebut dapat diketahui pengaruh Pengetahuan dengan nilai koefisien $\left(b_{1}\right)$ = 9,744 yang berarti bahwa bila skor variabel Pengetahuan bertambah 1 poin sementara variabel lainnya dipertahankan maka akan meningkatkan kinerja karyawan sebesar 9,744 poin . dengan tingkat signifikan $(p)=0,032<$ taraf kesalahan $(\alpha)=0,05$ maka variabel Pengetahuan berpengaruh Positif dan signifikan terhadap kinerja karyawan.

Hal ini sesuai dengan yang dikemukakan Spencer yang diadaptasi oleh (Asni, 2019), yang memandang bahwa pengetahuan sebagai salah satu karakteristik kompetensi memprediksi atau menyebabkan suatu kinerja efektif. Hasil pengujian ini bermakna, bahwa variabel 
merupakan satu kesatuan yang terintegrasi dan bersinergi mampu membentuk kinerja yang efektif.

\subsubsection{Pengaruh Keterampilan Terhadap Kinerja Pegawai}

Diketahui bahwa Variabel Keterampilan dengan nilai koefisien $\left(b_{2}\right)=9,203$ yang berarti bahwa bila skor variabel Keterampilan bertambah 1 poin sementara variabel lainnya dipertahankan maka akan meningkatkan kinerja karyawan sebesar 9,203 poin. dengan tingkat signifikan (p) = $0,000>\alpha=0,013$ maka variabel Keterampilan berpengaruh Positif dan Signifikan terhadap kinerja pegawai.

Hal ini memperkuat Pendapat Gibson dalam (Betty Zelda Siahaan, 2017), yang mengatakan bahwa kemampuan dan keterampilan merupakan faktor utama yang mempengaruhi prilaku dan kinerja individu. Lebih lanjut tentang keterampilan Dunnett's dalam (Halawa, 2019) skill adalah sebagai kapasitas yang dibutuhkan untuk melaksanakan suatu rangkaian tugas yang berkembang dari hasil pelatihan dan pengalaman, hal ini tentu akan meningkatkan Kinerja Karyawan.

\subsubsection{Pengaruh Perilaku Terhadap Kinerja Karyawan}

Dari hasil regresi dapat diketahui bahwa Variabel Perilaku dengan nilai koefisien $b_{3}=1,943$ yang berarti bahwa bila skor variabel Perilaku bertambah 1 poin sementara variabel lainnya dipertahankan maka akan meningkatkan kinerja pegawai sebesar 1,943 poin. dengan tingkat signifikan $(p)=0,024>\alpha=0,05$ maka pengaruh variabel Perilaku terhadap kinerja karyawan positif dan signifikan.

Hal ini sesuai dengan pendapat Amirullah (2002:40) bahwa : "Perilaku kerja sebagai status mental dan syaraf sehubungan dengan kesiapan untuk menganggapi, yang diorganisasi melalui pengalaman dan memilih pengaruh yang mengarahkan dan atau dinamis terhadap perilaku. Sehingga Apabila karyawan mempunyai sifat yang mendukung pencapaian tujuan organisasi, maka secara otomatis segala tugas yang dibebankan kepadanya akan dilaksanakan dengan sebaik-baiknya. Hal ini tentu akan meningkatkan kinerja karyawan.

\subsubsection{Pengaruh Pengalaman Kerja Terhadap Kinerja Karyawan}

Selanjutnya Variabel Pengalaman Kerja dengan nilai koefisien $\left(b_{4}\right)=10,598$ yang berarti bahwa bila skor variabel Pengalaman Kerja bertambah 1 poin sementara variabel lainnya dipertahankan maka akan meningkatkan kinerja karyawan sebesar 10,598 poin. dengan tingkat signifikan $(p)=0,006>\alpha=0,05$ maka variabel Pengalaman Kerja berpengaruh Positif dan Signifikan terhadap kinerja karyawan.

Hal ini sejalan dengan Knoers dan Hadinoto (2001:19) mengemukakan bahwa : "Pengalaman kerja adalah sebagai suatu proses pembelajaran dan pertambahan perkembangan potensi bertingkah laku baik dari pendidikan formal maupun non formal atau atau bisa Analisis Pengaruh Kompetensi Terhadap Kinerja Karyawan ......

DOI : 10.37531/mirai.v6i2.1307 
diartikan sebagai suatu proses yang membawa seseorang kepada suatu pola tingkah laku yang lebih tinggi. Dengan belajar dari pengalaman maka tingkah laku karyawan akan lebih baik, sehingga hal ini tentu akan meningkatkan kinerja pegawai.

\subsubsection{Pengaruh Kompetensi (Pengetahuan, Keterampilan, Perilaku dan Pengalaman Kerja ) Terhadap Kinerja Karyawan}

Secara keseluruhan hasil Pengujian terhadap Pengaruh Kompetensi terhadap Kinerja Pegawai Pada PT. Pos Indonesia Cabang Soppeng menunjukan pengaruh yang kuat, hal ini dibuktikan dengan nilai $\mathrm{F}_{\text {hitung }}=1,893$ dengan angka signifikansi $(\mathrm{p})=0,003<\alpha=0,05$ yang berarti bahwa Ho ditolak dan $\mathrm{H}_{\mathrm{a}}$ diterima. Atau dengan kata lain, memang benar bahwa variabel Kompetensi yang terdiri dari Pengetahuan, Keterampilan, Perilaku dan Pengalaman kerja secara simultan berpengaruh terhadap kinerja karyawan PT. Pos Indonesia Cabang Soppeng.

Hal ini sejalan dengan Pendapat Hutapea dan Thoha (2008:28) mengungkapkan bahwa ada empat komponen utama pembentukan kompetensi yaitu pengetahuan yang dimiliki seseorang, kemampuan, pengalaman, dan perilaku individu

\section{Kesimpulan dan Saran}

Berdasarkan pembahasan hasil penelitian sebagaimana yang telah dikemukakan di atas, maka dapat ditarik kesimpulan sebagai berikut : 1) Kompetensi yang terdiri dari variabel pengetahuan, keterampilan, perilaku dan pengalaman kerja memiliki pengaruh yang signifikan terhadap peningkatan kinerja karyawan pada PT. Pos Indonesia Cabang Soppeng. 2) Dari Hasil regresi, dapat diketahui bahwa diantara variabel pengetahuan, keterampilan, perilaku dan pengalaman kerja yang paling berpengaruh signifikan terhadap peningkatan kinerja karyawan pada PT. Pos Indonesia Cabang Soppeng adalah Pengalaman Kerja.

Berdasarkan uraian dan kesimpulan tersebut diatas maka dapat dikemukakan beberapa saran : 1) PT. Pos Indonesia Cabang Soppeng dapat meningkatkan Keterampilan Karyawan untuk meningkatkan kinerja karyawan. Peningkatan Keterampilan dapat dilakukan dengan memberikan Pelatihan- pelatihan kepada karyawan, baik itu Berupa Keterampilan menggunakan sarana dan prasarana seperti Komputer, serta Keterampilan untuk berkomunikasi dengan nasabah. 2) Sedangkan peningkatan Kinerja karyawan dapat ditingkatkan dengan memperbanyak Pengalaman Kerja Karyawan. Sehingga dengan Pengalaman Kerja yang tinggi akan meningkatkan hasil kerja karyawan dan kualitas pekerjaan karyawan.

\section{Referensi :}

Amirullah, 2002, Perilaku Konsumen, edisi pertama, cetakan pertama, Penerbit : Graha Ilmu, Yogyakarta 
Asmini, Sukma Aini, R. (2020). Pengaruh Sertifikasi dan Motivasi Terhadap Kinerja Guru SMPN 1 Donri - Donri. Metansi, 3(2), 23-30.

Asmini. (2019). Pengaruh Kompetensi Terhadap Kinerja Dosen Dpk Kopertis Wil . Ix Sulawesi Di Sulawesi Selatan Asmini. Metansi, 2(Oktober), 53-62.

Asni. (2019). Pengaruh kompetensi, motivasi dan lingkungan kerja terhadap kinerja pegawai biro administrasi umum dan keuangan universitas negeri makassar. Metansi, 2(April), 113.

Betty Zelda Siahaan. (2017). Pengaruh Kemampuan Kerja, Persepsi Peran dan Motivasi kerja terhadap kinerja pegawai Administrasi Universitas Negeri Jakarta. Jurnal Manajemen Pendidikan, 3(4), 246-256.

Gitosudarmo, Indriyo dan I Nyoman Sudita, 2008, Perilaku Organisasi, edisi pertama. BPFE, Yogyakarta

Knoers, A.M dan Hadinoto, S.R, 2001, Psikologi Perkembangan: Pengantar dalam Berbagai Bagiannya, Penerbit : Gajah Mada University Press, Yogyakarta

Halawa, W. (2019). Pengaruh Keterampilan Dan Efektivitas Kerja Terhadap Kinerja Karyawan Pada Pt. Jefrindo Consultant Medan. Manajemen Ekonomi Dan Bisnis, 111. http://repository.uma.ac.id/bitstream/123456789/10704/1/158320006 - Welinus Halawa - Fulltext.pdf

Hutapea, Parulian dan Nurianna Thoha, 2008, Kompetensi Plus : Teori, Desain, Kasus dan Penerapan untuk HR dan Organisasi yang Dinamis, Penerbit : Gramedia Pustaka Utama, Jakarta

Mangkunegara, Anwar Prabu, 2005, Evaluasi Kinerja Sumber Daya Manusia, edisi pertama, cetakan pertama, Penerbit : Refika Aditama, Bandun

Manullang, 2002, Manajemen Personalia, Penerbit : Ghalia Indonesia, Jakarta

Yunarsih, Tjutju dan Suwatno, 2008, Manajemen Sumber Daya Manusia, Teori, Aplikasi dan Isu Penelitian, Cetakan Kesatu, Penerbit : Alfabeta. Bandung. 